\title{
Effect of Salicylic Acid Formulations on Induced Plant Defense against Cassava Anthracnose Disease
}

\author{
Rungthip Sangpueak ${ }^{1}$, Piyaporn Phansak ${ }^{2}$, Kanjana Thumanu ${ }^{3}$, Supatcharee Siriwong ${ }^{3}$, Sopone Wongkaew ${ }^{1}$, \\ and Natthiya Buensanteai (iD) ${ }^{1 *}$ \\ ${ }^{1}$ School of Crop Production Technology, Institute of Agricultural Technology, Suranaree University of Technology, \\ Nakhon Ratchasima 30000, Thailand \\ ${ }^{2}$ Division of Biology, Faculty of Science, Nakhon Phanom University, Nakhon Phanom 48000, Thailand \\ ${ }^{3}$ Synchrotron Light Research Institute, Nakhon Ratchasima 30000, Thailand
}

(Received on February 2, 2021; Revised on May 11, 2021; Accepted on June 29, 2021)

This study was to investigate defense mechanisms on cassava induced by salicylic acid formulation (SA) against anthracnose disease. Our results indicated that the SA could reduce anthracnose severity in cassava plants up to $33.3 \%$ under the greenhouse condition. The $\beta$-1,3-glucanase and chitinase enzyme activities were significantly increased at $\mathbf{2 4}$ hours after inoculation (HAI) and decrease at 48 HAI after Colletotrichum gloeosporioides challenge inoculation, respectively, for cassava treated with SA formulation. Synchrotron radiation-based Fourier-transform infrared microspectroscopy spectra revealed changes of the $\mathrm{C}=\mathrm{H}$ stretching vibration $\left(3,000-2,800 \mathrm{~cm}^{-1}\right)$, pectin $\left(1,740-1,700 \mathrm{~cm}^{-1}\right)$, amide I protein $\left(1,700-1,600 \mathrm{~cm}^{-1}\right)$, amide II protein $\left(1,600-1,500 \mathrm{~cm}^{-1}\right)$, lignin $\left(1,515 \mathrm{~cm}^{-1}\right)$ as well as mainly $\mathrm{C}-\mathrm{O}-\mathrm{C}$ of polysaccharides $\left(1,300-1,100 \mathrm{~cm}^{-1}\right)$ in the leaf epidermal and mesophyll tissues treated with SA formulations, compared to those treated with fungicide carbendazim and distilled water after the challenged inoculation with $C$. gloeosporioides. The results indicate

\section{*Corresponding author.}

Phone) +66-882424536, FAX) +66-44224281

E-mail)natthiya@sut.ac.th

ORCID

Natthiya Buensanteai

https://orcid.org/0000-0002-1798-8006

Handling Editor : Inhwa Yeam

(c) This is an Open Access article distributed under the terms of the Creative Commons Attribution Non-Commercial License (http:// creativecommons.org/licenses/by-nc/4.0) which permits unrestricted noncommercial use, distribution, and reproduction in any medium, provided the original work is properly cited.

Articles can be freely viewed online at www.ppjonline.org. that biochemical changes in cassava leaf treated with SA played an important role in the enhancement of structural and chemical defense mechanisms leading to reduced anthracnose severity.

Keywords : anthracnose disease, cassava, formulation of salicylic acid, SR-FTIR

Anthracnose disease is widespread in cassava plants grown in various countries including Nigeria, Tanzania, Africa, India, and Thailand (William et al., 2012). The susceptibility varieties of cassava to cassava anthracnose disease (CAD) can affect the difference in disease severity. The damage caused by the disease has been reported in Congo, with severe destruction of up to $90 \%$ of cassava production. The disease is caused by Colletotrichum graminicola, C. gloeosporioides, and C. gloeosporioides f. sp. manihotis (Liu et al., 2019). In Thailand, anthracnose outbreaks have occurred in the northeastern region, it causes the loss of up to $80 \%$ of cassava products (Sangpueak et al., 2018). The physical symptoms of CAD are wilt, defoliation, necrotic lesions on leaves, bases of leaf petioles and stems and dieback (Liu et al., 2019; Sangpueak et al., 2018).

The new way to control CAD was salicylic acid (SA). SA has an essential role in the induction of defense response to stress responses (War et al., 2011). Furthermore, it has a role in regulating the components of the signaling pathway. Moreover, that can be contributed to cross-talk with many different paths act as intermediary plant resistance (Lu, 2009; Lu et al., 2016; War et al., 2011). The supporting data from induced resistance research, many commercial activator enhancers have been listed and used 
in crop production, e.g., Bion and Actigard (Syngenta), Elexa (chitosan; Safe Science), etc. The work of Gogbeu et al. (2015) in using SA, phosphoric acid, jasmonic acid, vitamin $\mathrm{C}$, and ascorbic acid as effective elicitors to control cassava diseases seem to be the latest development in this field. At present, there are several techniques used in conjunction with traditional and molecular techniques that can be used to investigate the structural and functional changes of plant defense response to plant diseases (Alonso-Simón et al., 2011). So, this study was to investigate the biochemical and behavior changes of cassava after being induced by SA formulations using the SR-FTIR technique together with plant defense enzyme activities.

\section{Materials and Methods}

SA preparation and fungal growth and inoculum. Six percent SA for the stock solution, dissolved in $70 \%$ ethanol, then dilute the final concentration of the stock solution with sterile water and adjusted to the final concentration of $200 \mathrm{mg} / \mathrm{l}$ before use.

C. gloeosporioides was cultured on potato dextrose agar incubated $25^{\circ} \mathrm{C}$ at 14 days before harvested. Spore suspensions of respective fungal isolates were prepared with approximately $1 \times 10^{6}$ conidia $/ \mathrm{ml}$ concentrations before sprayed onto three healthy cassava leaf until runoff.

Efficacy of SA to inducing resistance to anthracnose disease in cassava under a greenhouse condition. By design the randomized complete block design with four replications. Cassava stalks cv. Rayong 72 washed with $1 \%$ sodium hypochlorite solution for $2 \mathrm{~min}$, followed by washing with sterile water three times, after that drying for $5 \mathrm{~min}$ at room temperature. Subsequently, the cassava stalks were soaked for $5 \mathrm{~min}$ in the $200 \mathrm{mg} / \mathrm{l}$ of SA before planting. Soaking the stalks in distilled water and 10 $\mathrm{ml} / 201$ carbendazim 50\% WP (Bentus, Sotus International Co., Ltd., Nonthaburi, Thailand) are negative and positive controls. After planting, the $200 \mathrm{mg} / \mathrm{l} \mathrm{SA}$, water, and $10 \mathrm{ml} / 201$ carbendazim were sprayed onto the plants, two more times at 1 and 3 months. At $24 \mathrm{~h}$ after the last foliar spray, spore suspensions of $C$. gloeosporioides at $1 \times 10^{6}$ conidia/ml concentration was sprayed onto the healthy cassava leaf until runoff. After the inoculation, the leaves were put in plastic bags within $48 \mathrm{~h}$ under the greenhouse. Disease severity scoring of CAD was collected at 14 days after the inoculation as follows by Sangpueak et al. (2018). After the scoring, the leaves were collected to detect biochemical changes associated with plant defense using SR-FTIR microspectroscopy.
Differential level of $\beta$-1,3-glucanases and chitinases activities

Protein concentration. Protein extract method was described by Nair and Umamaheswaran (2016). Cassava leaf was kept at 0,24 , and 48 hours after infection (HAI). Grind $1 \mathrm{~g}$ of tissue in liquid nitrogen and $5 \mathrm{ml}$ extraction buffer that contained $0.1 \mathrm{M}$ sodium phosphate buffer ( $\mathrm{pH}$ 6.5) and polyvinyl pyrrolidone was added. The sample protein content was examined using the method from Bradford (1976), using bovine serum albumin to be a standard.

$\boldsymbol{\beta}$-1,3-glucanases activity. The crude protein extract (62.5 $\mu 1)$ was mixed with $1 \%(\mathrm{w} / \mathrm{v})$ laminarin (Sigma-Aldrich, St. Louis, MO, USA) in $0.05 \mathrm{M}$ sodium acetate buffer (pH 5.0) after that incubated in $10 \mathrm{~min}$ at $40^{\circ} \mathrm{C}$ (Żur et al., 2013). Stop reaction by the increase of $375 \mu 1$ ( $1 \%$ dinitro salicylic acid) and boiling $5 \mathrm{~min}$ in water. After that, cooling at $28^{\circ} \mathrm{C}$ (room temperature) and diluted 1:20. The reaction of enzyme was detected by measured at $500 \mathrm{~nm}$ followed by Prakongkha et al. (2013) and Żur et al. (2013). Enzyme activity is expressed in $\mu$ g glucose released $/ \mathrm{min} / \mathrm{g}$ fresh weight $/ \mathrm{mg}$ protein.

Chitinase activity. Chitinase activity was assayed by using crude protein extract $(400 \mu \mathrm{l})$ mixed with $0.1 \%(\mathrm{w} / \mathrm{v}) \mathrm{col}-$ loidal chitin in $0.05 \mathrm{M}$ sodium acetate buffer $\mathrm{pH} 5.0$ at ratio 1:1 (v/v). Then, incubation mixture at $37^{\circ} \mathrm{C}$ for $2 \mathrm{~h}$. Detection of N-acetyl glucosamine (GlcNAc) by absorbance at $585 \mathrm{~nm}$ followed by Prakongkha et al. (2013). For standard curve can be calculated using a standard curve prepared from GlcNAc.

Statistical analyses. The results of $\beta$-1,3-glucanases activity and chitinase activity were dissolved one-way analysis of variance (ANOVA) using SPSS version 14 (SPSS Inc., Chicago, IL, USA). The new Duncan's multiple range test (DMRT) was used to differentiate treatment at $P \leq 0.05$.

Biochemical changes analysis using SR-FTIR microspectroscopy

Sample preparation for SR-FTIR microspectroscopy. Cassava leaf samples were collected only the 5th top leaves at 7 days after treatment with SA treatment and inoculation with the pathogen for SR-FTIR microspectroscopic analysis. Leaves at the same position from that of the negative and positive controls were also included for the comparison. The analysis proceeded in a completely randomized design within three replications. The samples were subsequently cut to $1 \times 1 \mathrm{~cm}$ size and embedded in the optimal cutting temperature compound, followed by 
Quick-freezing in liquid nitrogen. Then, the samples were stored at a $-80^{\circ} \mathrm{C}$ as long as to do cryo-sectioning process. Subsequently, each cassava leaf sample was cut crosswise to $10 \mu \mathrm{m}$ using a microtome of cryostat (Leica $3050 \mathrm{~S}$, Jena, Germany) and stick on BaF2 window size $13 \times 2 \mathrm{~mm}$ for SR-FTIR microspectroscopy.

Data measurement of SR-FTIR microspectroscopy. The determination was operated with a mapping by using a size of aperture at $10 \times 10 \mu \mathrm{m}$ with a resolution of 4 $\mathrm{cm}^{-1}$, with 64 scans. By used spectra was received with FTIR spectrometer (Vertex 70 from Bruker Optics, Ettlingen, Germany) together with infrared (IR) microscope (Hyperion series 2000, Bruker) with MCT detector refrigerate in liquid nitrogen through the determination range from 3,000 to $800 \mathrm{~cm}^{-1}$. Spectral equipment control was carried on by OPUS 7.2 software (Bruker Optics Ltd.) at the Synchrotron Light Research Institute.

Cassava image analysis. IR imaging of cassava tissues was created and analyzed using Cytospec 1.3.4 (Cytospec Inc., Croton-On-Hudson, NY, USA). The peak was transferred to the second derivative by using 13 smoothing points and vector normalized for the differing sample. The image structuring can be using a univariate model that generates up to peak intensity and peak area typically have meanings as chemical group maps. Hierarchical cluster analysis (HCA) was operated to separate the different biochemical components sample overranges of $(3,000$ 2,800 and $\left.1,800-900 \mathrm{~cm}^{-1}\right)$. The $2 \mathrm{D}$ cluster maps are saved as figure files with a particular color to define a cluster. The spectra of cassava tissue from treated and non-treated plants were assays by principal cluster analysis (PCA) to
Table 1. Efficacy of salicylic acid on severity of cassava anthracnose disease caused by Colletotrichum gloeosporioides under a greenhouse condition at 14 day after inoculation

\begin{tabular}{lc}
\hline \multicolumn{1}{c}{ Treatment } & Disease severity $(\%)^{\mathrm{a}}$ \\
\hline Salicylic acid $(200 \mathrm{mg} / \mathrm{l})$ & $33.3 \mathrm{c}$ \\
Carbendazim $(10 \mathrm{ml} / 20 \mathrm{l})$ & $66.6 \mathrm{~b}$ \\
Water (control) & $77.7 \mathrm{a}$ \\
F-test & $* *$ \\
$\mathrm{CV} \%$ & 7.33 \\
\hline
\end{tabular}

$\mathrm{CV}$, coefficient of variation.

${ }^{a}$ Numbers within a column followed by different letters are significantly different by DMRT $(P \leq 0.05)$. **P $<0.01$ compared to control.

differentiate the different biochemical composition of the tissue.

PCA analysis. Spectra from each cluster were assayed using PCA for differentiating biochemical elemental of tissue. The process was using 2 nd derivative and vector normalized (Savitzky-Golay method, 3rd polynomial, 9 smoothing points) from the Unscrambler software version 9.7 (CAMO Software AS, Oslo, Norway).

\section{Results}

Efficacy of SA formulation in inducing resistance to anthracnose disease. At 14 days after the last foliar spray with SA at $200 \mathrm{mg} / \mathrm{l}$, anthracnose severity on cassava treated with SA was among the lowest at $33.3 \%$, comparable to that treated with carbendazim. The severity observed on the negative control, where the cassava was treated with water,

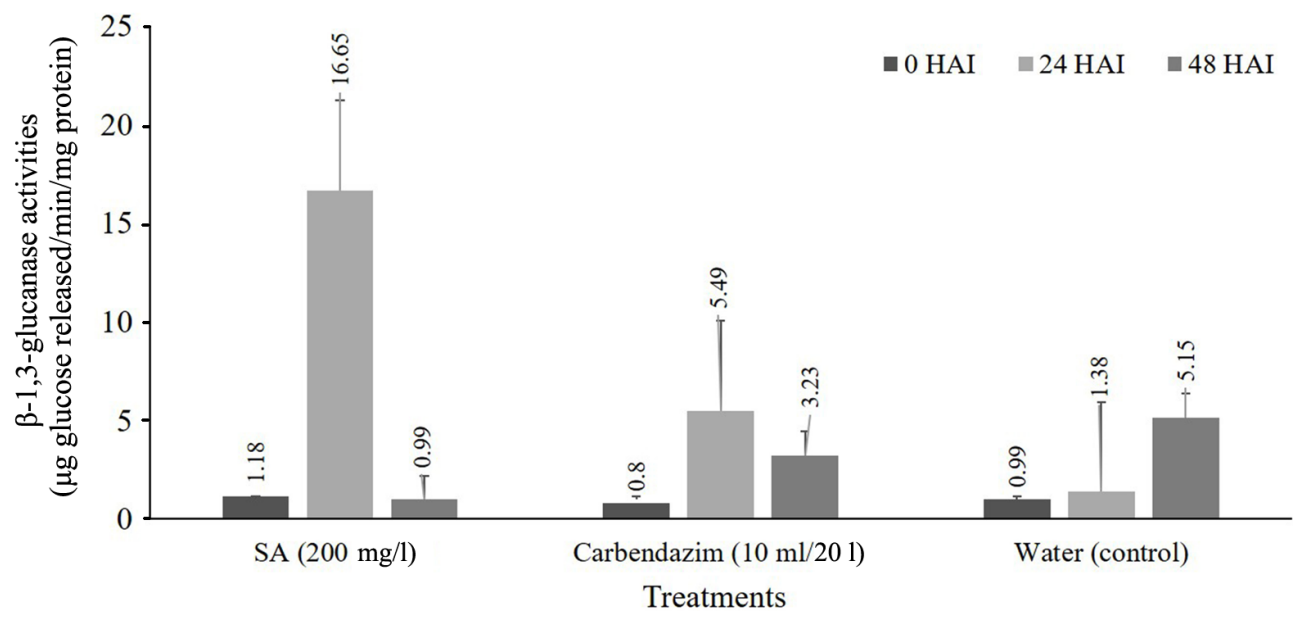

Fig. 1. Enhancement of $\beta$-1,3-glucanase activities in cassava leave soaking and foliar spray treatment at 0,24 , and 48 hours after inoculation (HAI) with Colletotrichum gloeosporioides. 


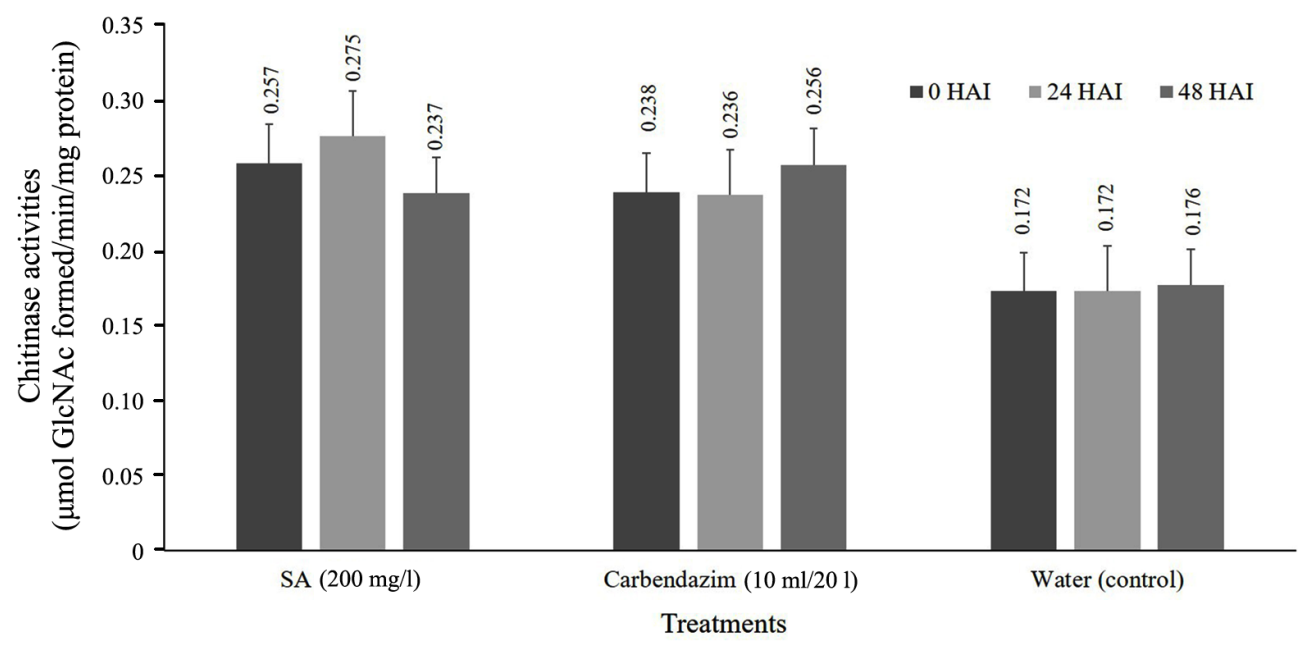

Fig. 2. Enhancement of chitinase activities in cassava leave soaking and foliar spray treatment at 0, 24, and 48 hours after inoculation (HAI) with Colletotrichum gloeosporioides. SA, salicylic acid.

was among the highest at $77.7 \%$ (Table 1$)$.

$\boldsymbol{\beta}$-1,3-glucanases activity. Induction of $\beta$-1,3-glucanase by treated with SA formulation and inoculation with pathogen showed the increased response of $\beta$-1,3-glucanase level of SA. It has increased in $24 \mathrm{HAI}$ at $16.65 \mu \mathrm{g}$ glucose released $/ \mathrm{min} / \mathrm{mg}$ protein was significantly higher compared with non-treated plant and decreased at 48 HAI significantly different when compared with control (Fig. 1).

Chitinase activity. Chitinase activity of cassava leaf after treated with SA formulation and inoculation with fungal pathogen. The results show that chitinase activity was observed in all of the treatments of SA increased rapidly at $24 \mathrm{HAI}$ and decrease at $48 \mathrm{HAI}$ significantly different when compared with non-treated plant (control). SA can be induced by the accumulation of chitinase has the highest level at $0.275 \mu \mathrm{mol} \mathrm{GlcNAc}$ formed $/ \mathrm{min} / \mathrm{mg}$ protein (Fig. 2).

Biochemical changes analysis using SR-FTIR microspectroscopy. The purpose of this experiment to study the effect of SA formulations compared to that of the fungicide carbendazim of cassava physiological defense response. The biochemical and cell configuration of cassava leaf in epidermal and mesophyll tissues by using SR-FTIR. Biochemical changes were compared in the treated and nontreated cassava leaf (Fig. 3A-C). The IR images indicated absorbance intenseness of imaging were relative to color change: blue (show the lowest of chemical imaging) $<$ green $<$ red (show the highest of chemical imaging) (Fig. 3J-L). HCA was applicable to separate spectra depending on 5 clusters in the range of 3,000-900 $\mathrm{cm}^{-1}$, and changed the color of different groups. The chemical imaging of microstructures of cassava leaf is shown in Fig. 3D-I. Leaf tissues of the negative and positive controls were also observed to correlate the changes of spectral initiate in the proteins, lipids, and polysaccharides to that of the elicitortreated tissues.

Spectra and secondary derivative average spectrum in the phase of 3,000-2,800 and 1,800-900 $\mathrm{cm}^{-1}$ were differences of the epidermal and mesophyll tissues (Fig. 4). Amide II protein $\left(1,600-1,500 \mathrm{~cm}^{-1}\right)$, no significant difference was found in the cassava epidermis of those treated with the SA formulation compared to those of the positive and negative controls (Table 2). The differences $\mathrm{C}=\mathrm{H}$ stretching vibration $\left(3,000-2,800 \mathrm{~cm}^{-1}\right)$, pectin $\left(1,740-1,700 \mathrm{~cm}^{-1}\right)$, amide I protein $\left(1,700-1,600 \mathrm{~cm}^{-1}\right)$, lignin $\left(1,515 \mathrm{~cm}^{-1}\right)$, mainly $\mathrm{C}-\mathrm{O}-\mathrm{C}$ of polysaccharides $\left(1,300-1,100 \mathrm{~cm}^{-1}\right)$ were found at some vibrational peaks of (Fig. 4A and B). Mesophyll tissue of cassava leaf treated with SA also had a significant difference in the cassava epidermis of those treated with the SA formulation compared to those of the positive and negative controls. At the vibrational peaks of pectin, amide I protein, amide II protein, lignin, mainly $\mathrm{C}-\mathrm{O}-\mathrm{C}$ of polysaccharides while spectrum of $\mathrm{C}-\mathrm{H}$ stretching was no significant difference in mesophyll tissue were calculated in Table 3 (Fig. 4C and D).

This information represents course changes of biochemical in cassava after being treated of SA formulation, elucidating the response to defense mechanisms against anthracnose disease. To used PCA technique was applied to analyze biochemical changes. This technique is useful in analyses of bio spectroscopic data by making it visible 

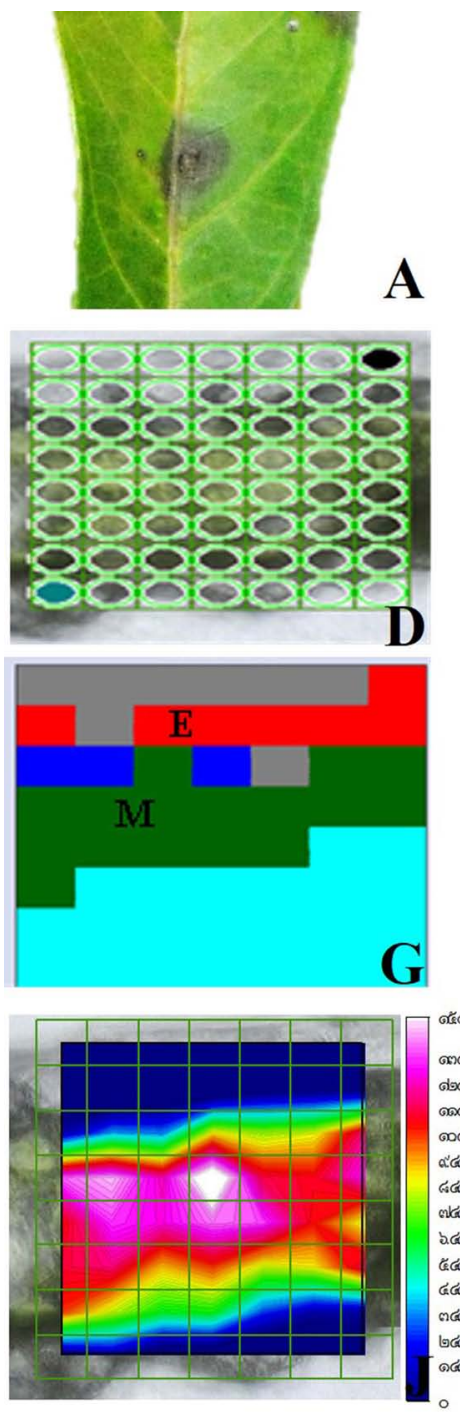

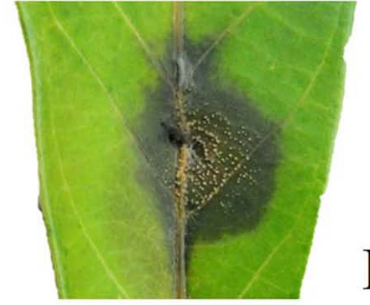

B
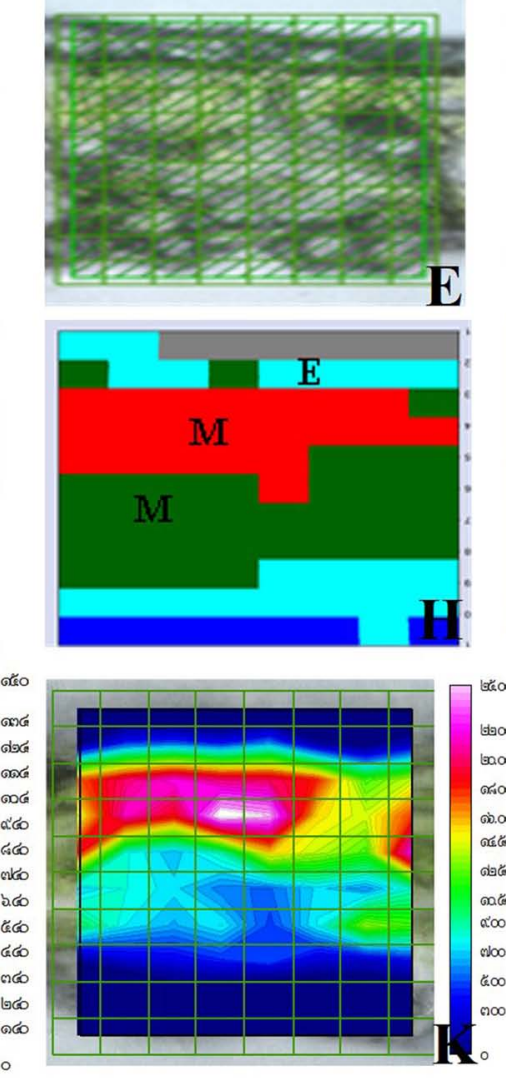
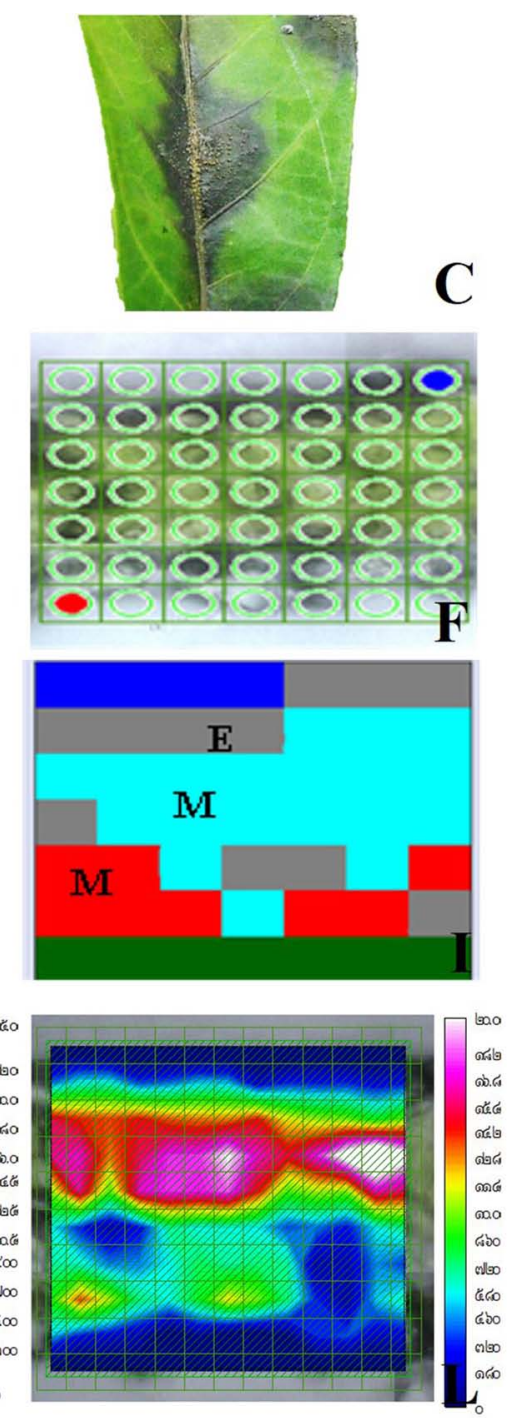

Fig. 3. Biochemical changes of cassava after treated with treatment and fungal inoculation used synchrotron radiation-based Fouriertransform infrared microspectroscopy. (A) Cassava treated with salicylic acid. (B) Cassava treated with carbendazim. (C) Cassava treated with water (the control). (D-I) Map and hierarchical cluster analysis map of cassava treated with treatment. (J-L) Chemical mapping was proportional to color change: blue (the lowest) $<$ green $<$ red (the highest).

of similar spectra in scores and loading plots (data not showed) between treated and non-treated leaves. In addition, the data analysis represents that the $\mathrm{PC} 1$ and $\mathrm{PC} 2$ regularly are the most different clustering two or three groups. The red points representing SA treatment could be easily distinguished from the blue and green points of the water control and carbendazim. The PC1 and PC2 loading of SA treatment were shown that separation between $\mathrm{PC} 1$ and PC2 corresponded to total variance of $49 \%$ from $\mathrm{PC} 1$ and $14 \%$ in epidermis tissue (Fig. 5A and C). For mesophyll tissue found that the separation between PC1 and PC2 corresponded to total variance of $64 \%$ from $\mathrm{PC} 1$ and $13 \%$ (Fig.
5B and D). The results show structural and physiological changes associated with the defense mechanism in cassava.

\section{Discussion}

In this present study, the most efficacy for induction was obtained at concentrations at $200 \mathrm{ppm}$ of SA and used to compare with fungicide and water control. SA can reduce disease severity by $33.3 \%$ compared with the control. Similar results were observed to previous studies, In hydroponic tomato plants, with the treatment of SA at $200 \mu \mathrm{M}$ showed to control $9 \%$ of leaf yellowing of Fusarium wilt, compared 

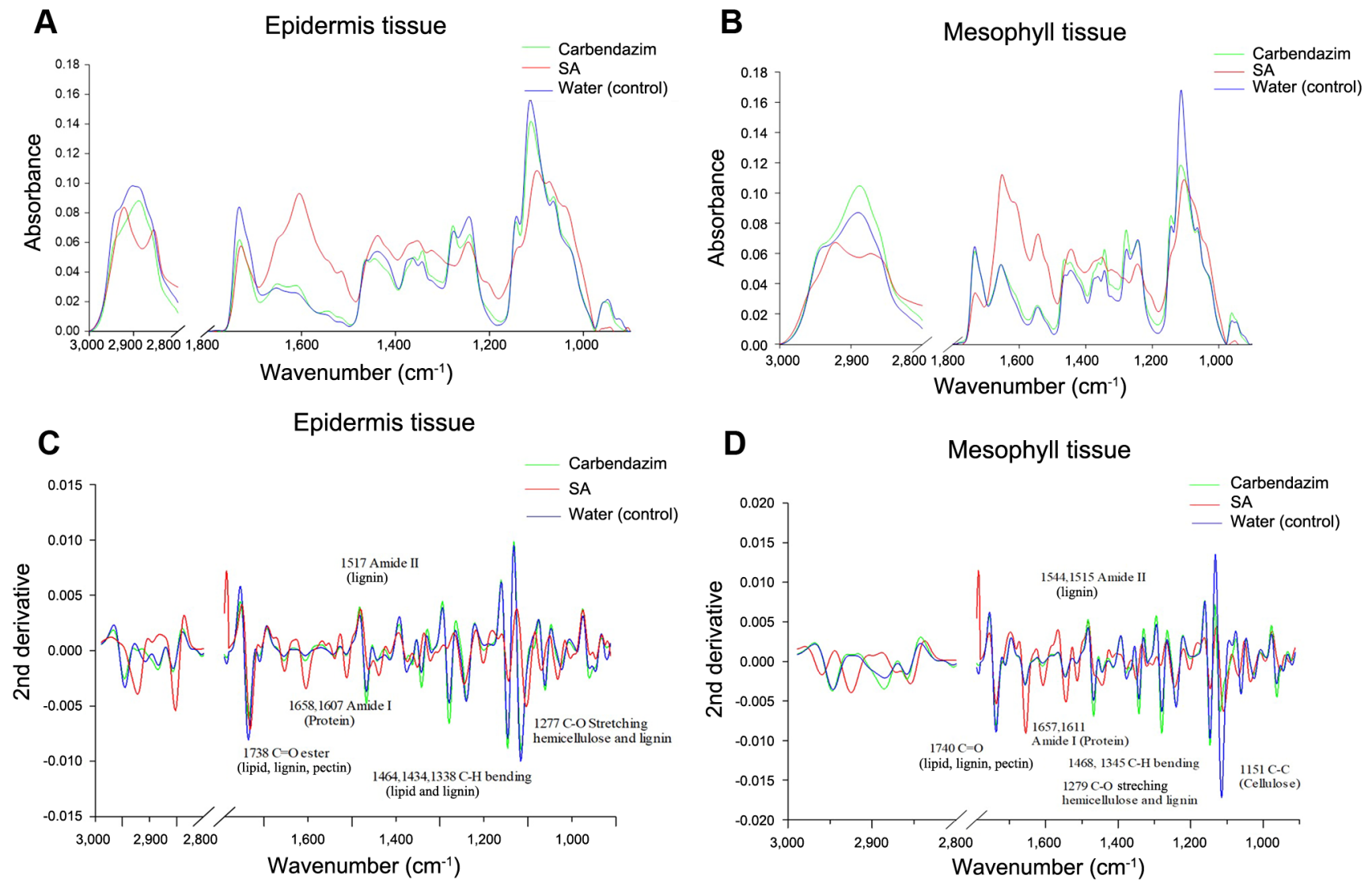

Fig. 4. Representative original average spectra in the range of 3,000-2,810 $\mathrm{cm}^{-1}$ and 1,800-900 cm $\mathrm{cm}^{-1}$ (A) Original average spectra in epidermis tissues of cassava leaf. (B) Second derivative in epidermis tissues of cassava leaf. (C) Original average spectra in mesophyll tissues of cassava leaf. (D) Second derivative in epidermis tissues of cassava leaf mesophyll tissues. SA, salicylic acid.

with the control which exhibited disease incidence reaching $70 \%$, at two weeks after inoculation (Jendoubi et al., 2015). Exogenous application of $50 \mu \mathrm{M} \mathrm{SA}$ at 15 days before inoculation reduced the severity of leaf curl virus in tomato (Ong and Cruz, 2016). And Koo et al. (2020) reported that SA effects enhanced disease resistance upon exogenous SA application in plants against the different species of pathogens, including Fusarium oxysporum, Alternaria alternata, Magnaporthe grisea, Colletotrichum gloeosporides, Xanthomonas spp., viruses and etc.

Also, SA can be induced, accumulate methodically are linked to systemic acquired response to biotic and abiotic stresses in different plants (Gao et al., 2015; Koo et al., 2020). These results show that the change of $\beta-1,3-$ glucanase and chitinase at $24 \mathrm{HAI}$ after last sprayed with SA formulation and inoculation with fungal pathogen that had been related to plant defense mechanisms against pathogen attack and can destroy the constituents of cell walls of $C$. gloeosporioides in the attacked cassava tissue (Gupta et al., 2012; Santos et al., 2004). These enzymes an essential role in induced cassava resistance to pathogens (Thakur and Sohal, 2013). It can be substantiated that elicitor can enhance the resistance of pathogenesis-related (PR)proteins proteins and also act as increase plants resistance to different pathogens (El-kereamy et al., 2011; Jayaraj et al., 2004; Koo et al., 2020).

In addition, plants defense depends on the contribution of the cell wall to against an infection to pathogens. Because of the synchrotron light that gives the intensity and source brighter than conventional sources, it helps to reduce the analysis time compared to using conventional IR Source (Baker et al., 2014; Wang et al., 2016). The SR-FTIR mapping displays the integrated area of proteins, lipids, and polysaccharides at absorption between 3,000-2,800 and $1,800-900 \mathrm{~cm}^{-1}$ (Wang et al., 2016). The peak variation between treatments indicated that the changes in the intensity of lignin, lipids, amine I of protein, and amine II of lignin in epidermis and mesophyll tissues. The epidermis and mesophyll tissues treated by SA formulations showed spectra higher than those of the control significantly at the 
Table 2. The integral area of average spectra from epidermis of cassava leaf treated with salicylic acid and challenge inoculation with Colletotrichum gloeosporioides

\begin{tabular}{|c|c|c|c|c|c|c|}
\hline \multirow[b]{2}{*}{ Treatments } & \multicolumn{6}{|c|}{ Functional groups } \\
\hline & $\begin{array}{c}\mathrm{C}=\mathrm{H} \text { stretching } \\
\text { vibration } \\
(3,000-2,800 \\
\left.\mathrm{cm}^{-1}\right)\end{array}$ & $\begin{array}{c}\text { Pectin } \\
(1,740-1,700 \\
\left.\mathrm{cm}^{-1}\right)\end{array}$ & $\begin{array}{c}\text { Amide I } \\
\text { protein } \\
(1,700-1,600 \\
\left.\mathrm{cm}^{-1}\right)\end{array}$ & $\begin{array}{l}\text { Amide II } \\
\text { protein } \\
(1,600-1,500 \\
\left.\mathrm{cm}^{-1}\right)\end{array}$ & $\begin{array}{c}\text { Lignin } \\
\left(1,515 \mathrm{~cm}^{-1}\right)\end{array}$ & $\begin{array}{l}\text { Mainly } \mathrm{C}-\mathrm{O}-\mathrm{C} \text { of polysaccharides; } \\
\text { very complex and depends upon } \\
\text { contributions from polysaccharides, } \\
\text { cellulose, hemicellulose, and pectin } \\
\qquad\left(1,300-1,100 \mathrm{~cm}^{-1}\right)\end{array}$ \\
\hline $\begin{array}{l}\text { Salicylic acid } \\
\qquad(200 \mathrm{mg} / \mathrm{l})\end{array}$ & $\begin{array}{c}0.0400 \pm \\
0.008 \mathrm{a}\end{array}$ & $\begin{array}{l}0.0260 \pm \\
0.002 \mathrm{ab}\end{array}$ & $\begin{array}{c}0.0223 \pm \\
0.003 \mathrm{a}\end{array}$ & $\begin{array}{c}0.0016 \pm \\
0.000\end{array}$ & $\begin{array}{c}0.0076 \pm \\
0.001 \mathrm{a}\end{array}$ & $0.0443 \pm 0.006 \mathrm{~b}$ \\
\hline $\begin{array}{l}\text { Carbendazim } \\
\qquad(10 \mathrm{ml} / 20 \mathrm{l})\end{array}$ & $\begin{array}{c}0.0236 \pm \\
0.003 \mathrm{~b}\end{array}$ & $\begin{array}{c}0.0253 \pm \\
0.001 \mathrm{~b}\end{array}$ & $\begin{array}{c}0.0073 \pm \\
0.000 \mathrm{~b}\end{array}$ & $\begin{array}{c}0.0013 \pm \\
0.001\end{array}$ & $\begin{array}{c}0.0010 \pm \\
0.000 \mathrm{~b}\end{array}$ & $0.0893 \pm 0.004 \mathrm{a}$ \\
\hline Water (control) & $\begin{array}{c}0.0256 \pm \\
0.001 \mathrm{~b}\end{array}$ & $\begin{array}{c}0.0280 \pm \\
0.001 \mathrm{a}\end{array}$ & $\begin{array}{c}0.0040 \pm \\
0.000 \mathrm{~b}\end{array}$ & $\begin{array}{c}0.0010 \pm \\
0.000\end{array}$ & $\begin{array}{c}0.0006 \pm \\
0.000 \mathrm{c}\end{array}$ & $0.0823 \pm 0.002 \mathrm{a}$ \\
\hline F-test & $*$ & $*$ & $* *$ & ns & $* *$ & $* *$ \\
\hline
\end{tabular}

Different letters indicate significant differences $(P \leq 0.05)$. ${ }^{*} P<0.05$ compared to control, ${ }^{*} P<0.01$ compared to control; ns, not significant.

Table 3. The integral area of average spectra from mesophyll of cassava leaf treated with salicylic acid and challenge inoculation with Colletotrichum gloeosporioides

\begin{tabular}{|c|c|c|c|c|c|c|}
\hline \multirow[b]{2}{*}{ Treatments } & \multicolumn{6}{|c|}{ Functional groups } \\
\hline & $\begin{array}{c}\mathrm{C}=\mathrm{H} \text { stretching } \\
\text { vibration } \\
(3,000-2,800 \\
\left.\mathrm{cm}^{-1}\right)\end{array}$ & $\begin{array}{c}\text { Pectin } \\
(1,740-1,700 \\
\left.\mathrm{cm}^{-1}\right)\end{array}$ & $\begin{array}{c}\text { Amide I } \\
\text { protein } \\
(1,700-1,600 \\
\left.\mathrm{cm}^{-1}\right)\end{array}$ & $\begin{array}{l}\text { Amide II } \\
\text { protein } \\
(1,600-1,500 \\
\left.\mathrm{cm}^{-1}\right)\end{array}$ & $\begin{array}{l}\text { Lignin } \\
\left(1,515 \mathrm{~cm}^{-1}\right)\end{array}$ & $\begin{array}{l}\text { Mainly } \mathrm{C}-\mathrm{O}-\mathrm{C} \text { of polysaccharides; } \\
\text { very complex and depends upon } \\
\text { contributions from polysaccharides, } \\
\text { cellulose, hemicellulose, and pectin } \\
\qquad\left(1,300-1,100 \mathrm{~cm}^{-1}\right)\end{array}$ \\
\hline $\begin{array}{l}\text { Salicylic acid } \\
\qquad(200 \mathrm{mg} / \mathrm{l})\end{array}$ & $\begin{array}{c}0.0400 \pm \\
0.008 \mathrm{a}\end{array}$ & $\begin{array}{l}0.0260 \pm \\
0.002 \mathrm{ab}\end{array}$ & $\begin{array}{c}0.0223 \pm \\
0.003 \mathrm{a}\end{array}$ & $\begin{array}{c}0.0016 \pm \\
0.000\end{array}$ & $\begin{array}{c}0.0076 \pm \\
0.001 \mathrm{a}\end{array}$ & $0.0443 \pm 0.006 \mathrm{~b}$ \\
\hline $\begin{array}{l}\text { Carbendazim } \\
\qquad(10 \mathrm{ml} / 20 \mathrm{l})\end{array}$ & $\begin{array}{c}0.0236 \pm \\
0.003 \mathrm{~b}\end{array}$ & $\begin{array}{c}0.0253 \pm \\
0.001 \mathrm{~b}\end{array}$ & $\begin{array}{c}0.0073 \pm \\
0.000 \mathrm{~b}\end{array}$ & $\begin{array}{c}0.0013 \pm \\
0.001\end{array}$ & $\begin{array}{c}0.0010 \pm \\
0.000 \mathrm{~b}\end{array}$ & $0.0893 \pm 0.004 \mathrm{a}$ \\
\hline Water (control) & $\begin{array}{c}0.0256 \pm \\
0.001 \mathrm{~b}\end{array}$ & $\begin{array}{c}0.0280 \pm \\
0.001 \mathrm{a}\end{array}$ & $\begin{array}{c}0.0040 \pm \\
0.000 \mathrm{~b}\end{array}$ & $\begin{array}{c}0.0010 \pm \\
0.000\end{array}$ & $\begin{array}{c}0.0006 \pm \\
0.000 \mathrm{c}\end{array}$ & $0.0823 \pm 0.002 \mathrm{a}$ \\
\hline F-test & $*$ & $*$ & $* *$ & ns & $* *$ & $* *$ \\
\hline
\end{tabular}

Different letters indicate significant differences $(P \leq 0.05) . * P<0.05$ compared to control, $* * P<0.01$ compared to control; ns, not significant.

vibrational peaks of $\mathrm{C}=\mathrm{H}$ stretching vibration, pectin, amide I protein, lignin, mainly $\mathrm{C}-\mathrm{O}-\mathrm{C}$ of polysaccharides that can help to improve cassava cell wall structure. Consistent research of Thanh et al. (2017), the present study, demonstrates that the higher ratios of pectin and lignin were observed in plants sprayed with SA. SA treated on rice plants shown higher amide I, $\beta$-sheet structure, and lipids. This physical defense may include the amplification of cell wall thickenings such as the blockage of plant vessels (Jendoubi et al., 2015). The results show physiological and chemical changes with the defense mechanism in cassava against anthracnose disease.
Conclusion. Cassava treated with SA formulation could be reduced anthracnose disease caused by $C$. gloeosporioides and can be the induction of $\beta$-1,3-glucanase and chitinase activity. By treatment with SA is correlated by the increased resistance of the cassava tissues against infection by the C. gloeosporioides pathogen. Moreover, SRFTIR microspectroscopy could be used as equipment for detecting biochemical changes at the most resolution. It's showed the structural and biochemical of different cassava tissues that were treated with elicitors. This research offers that the changes of structure in cassava tissue have interaction with plant defense responses after stimulated with the SA formulation. Besides, one solution of products contain- 

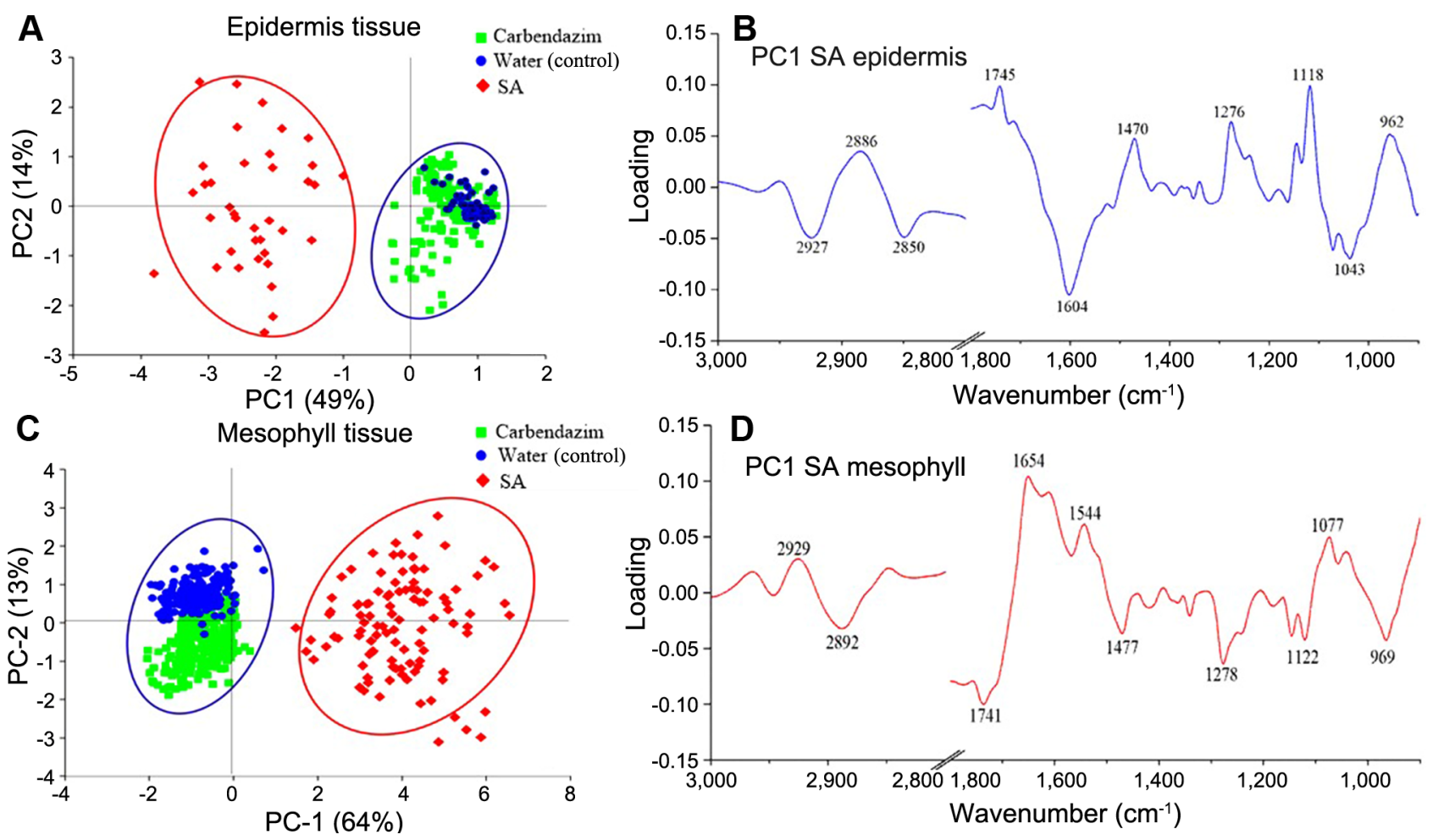

Fig. 5. (A-D) Principal cluster analysis analysis in cassava leaf treated with 200 ppm salicylic acid (SA) and compared with cabendazim and water and challenge inoculated with Colletotrichum gloeosporioides at 14 days after inoculation under a greenhouse condition.

ing SA, especially SA would be to introduce an alternative product to prevent yield loss of cassava-related infections from anthracnose disease pathogen.

\section{Conflicts of Interest}

No potential conflict of interest relevant to this article was reported.

\section{Acknowledgments}

The authors wish to express grateful the research assistant of Plant Pathology and Biopesticide Laboratory, Suranaree University of Technology, for the technical assistance, and Synchrotron Light Research Institute (Public Organization) for providing the SR-FTIR instruments and beam times.

This work was supported by the Research and Researcher for Industries (RRi), Thailand Research Funds [grant number PHD59I0084] to Miss Rungthip Sangpueak.

\section{References}

Alonso-Simón, A., García-Angulo, P., Mélida, H., Encina, A., Álvarez, J. M. and Acebes, J. L. 2011. The use of FTIR spec- troscopy to monitor modifications in plant cell wall architecture caused by cellulose biosynthesis inhibitors. Plant Signal. Behav. 6:1104-1110.

Baker, M. J., Trevisan, J., Bassan, P., Bhargava, R., Butler, H. J., Dorling, K. M., Fielden, P. R., Fogarty, S. W., Fullwood, N. J., Heys, K. A., Hughes, C., Lasch, P., Martin-Hirsch, P. L., Obinaju, B., Sockalingum, G. D., Sulé-Suso, J., Strong, R. J., Walsh, M. J., Wood, B. R., Gardner, P. and Martin, F. L. 2014. Using Fourier transform IR spectroscopy to analyze biological materials. Nat. Protoc. 9:1771-1791.

El-kereamy, A., El-sharkawy, I., Ramamoorthy, R., Taheri, A., Errampalli, D., Kumar, P. and Jayasankar, S. 2011. Prunus domestica pathogenesis-related protein-5 activates the defense response pathway and enhances the resistance to fungal infection. PLoS ONE 6:e17973.

Gao, Q. M., Zhu, S., Kachroo, P. and Kachroo, A. 2015. Signal regulators of systemic acquired resistance. Front. Plant Sci. $6: 228$.

Gogbeu, S. J., Sekou, D., Kouakou, K. J., Dogbo, D. O. and Bekro, Y.-A. 2015. Improvement of cassava resistance to Colletotrichum gloeosporioïdes by salicylic acid, phosphorous acid and fungicide Sumi 8. Int. J. Curr. Microbiol. App. Sci. 4:854865.

Gupta, P., Ravi, I. and Sharma, V. 2012. Induction of $\beta-1,3-$ glucanase and chitinase activity in the defense response of Eruca sativa plants against the fungal pathogen Alternaria 
brassicicola. J. Plant Interact. 8:155-161.

Jayaraj, J., Muthukrishnan, S., Liang, G. H. and Velazhahan, R. 2004. Jasmonic acid and salicylic acid induce accumulation of $\beta$-1,3-glucanase and thaumatin-like proteins in wheat and enhance resistance against Stagonospora nodorum. Biol. Plant. 48:425-430.

Jendoubi, W., Harbaoui, K. and Hamada, W. 2015. Salicylic acidinduced resistance against Fusarium oxysporum f. sp. radicislycopercisi in hydroponic grown tomato plants. J. New Sci. 21:985-995.

Koo, Y. M., Heo, A. Y. and Choi, H. W. 2020. Salicylic acid as a safe plant protector and growth regulator. Plant Pathol. J. 36:1-10.

Liu, X., Shi, T., Li, B., Cai, J., Li, C. and Huang, G. 2019. Colletotrichum species associated with cassava anthracnose in China. J. Phytopathol. 167:1-9.

Lu, H. 2009. Dissection of salicylic acid-mediated defense signaling networks. Plant Signal. Behav. 4:713-717.

Lu, H., Greenberg, J. T. and Holuigue, L. 2016. Editorial: salicylic acid signaling networks. Front. Plant Sci. 7:238.

Nair, A. B. and Umamaheswaran, K. 2016. Enzymatic responses to SriLankan cassava mosaic virus infection in cassava plants after grafting. Int. J. Appl. Pure Sci. Agric. 2:165-170.

Ong, S. and Cruz, F. C. S. 2016. Effect of exogenous application of salicylic acid on the severity of tomato leaf curl disease. $J$. Int. Soc. Southeast Asian Agric. Sci. 22:137-145.

Prakongkha, I., Sompong, M., Wongkaew, S., Athinuwat, D. and Buensanteai, N. 2013. Foliar application of systemic acquired resistance (SAR) inducers for controlling grape anthracnose caused by Sphaceloma ampelinum de Bary in Thailand. Afr. J. Biotechnol. 12:5148-5156.

Sangpueak, R., Phansak, P. and Buensanteai, N. 2018. Morpho- logical and molecular identification of Colletotrichum species associated with cassava anthracnose in Thailand. J. Phytopathol. 166:129-142

Santos, I. S., Da Cunha, M., Machado, O. L. T. and Gomes, V. M. 2004. A chitinase from Adenanthera pavonina L. seeds: purification, characterisation and immunolocalisation. Plant Sci. 167:1203-1210.

Thakur, M. and Sohal, B. S. 2013. Role of elicitors in inducing resistance in plants against pathogen infection: a review. ISRN Biochem. 2013:762412.

Thanh, T. L., Thumanu, K., Wongkaew, S., Boonkerd, N., Teaumroong, N., Phansak, P. and Buensanteai, N. 2017. Salicylic acid-induced accumulation of biochemical components associated with resistance against Xanthomonas oryzae pv. oryzae in rice. J. Plant Interact. 12:108-120.

Wang, H., Kashyap, Y. and Sawhney, K. 2016. From synchrotron radiation to lab source: advanced speckle-based X-ray imaging using abrasive paper. Sci. Rep. 6:20476.

War, A. R., Paulraj, M. G., War, M. Y. and Ignacimuthu, S. 2011. Role of salicylic acid in induction of plant defense system in chickpea (Cicer arietinum L.). Plant Signal. Behav. 6:17871792.

William, M. N. M., Mbega, E. R. and Mabagala, R. B. 2012. An outbreak of anthracnose caused by Colletotrichum gloesporioides f. sp. manihotis in Cassava in North Western Tanzania. Am. J. Plant Sci. 3:596-598.

Żur, I., Gołębiowska, G., Dubas, E., Golemiec, E., Matušíková, I., Libantová, J. and Moravčíková, J. 2013. $\beta$-1,3-glucanase and chitinase activities in winter triticales during cold hardening and subsequent infection by Microdochium nivale. Biologia 68:241-248. 